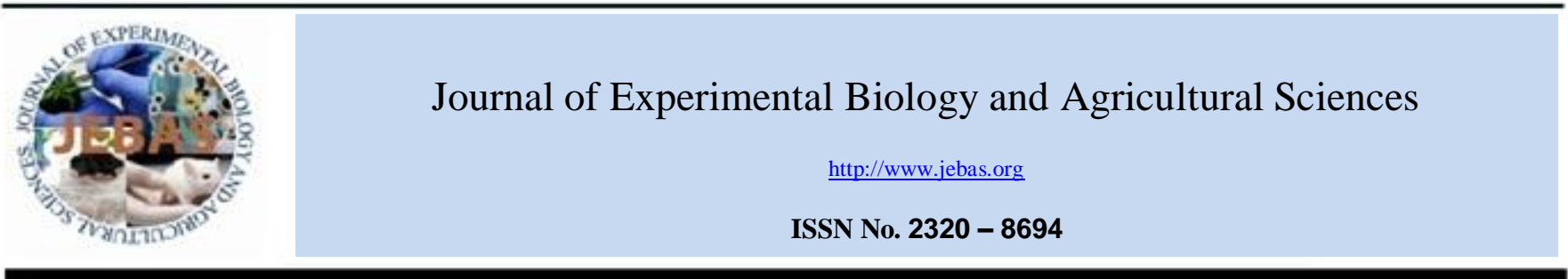

\title{
JAPANESE ENCEPHALITIS, RECENT PERSPECTIVES ON VIRUS GENOME, TRANSMISSION, EPIDEMIOLOGY, DIAGNOSIS AND PROPHYLACTIC INTERVENTIONS
}

\author{
Arumugam Karthikeyan ${ }^{1}$, Subramaniyan Shanmuganathan ${ }^{2}$, Selvaraj Pavulraj ${ }^{3}$, Govinthasamy \\ Prabakar $^{4}$, Selvaraj Pavithra ${ }^{5}$, Kannan Porteen ${ }^{6}$, Govindaraj Elaiyaraja ${ }^{7}$, Yashpal Singh Malik ${ }^{8 *}$
}

\footnotetext{
${ }^{1}$ Department of Veterinary Public Health and Epidemiology, Madras Veterinary College, Chennai 600007, Tamilnadu, India

${ }^{2}$ Division of Virology, Indian Veterinary Research Institute, Mukteswar, Uttarakhand-263138, India

${ }^{3}$ Institut fürVirologie, FreieUniversität Berlin, Berlin-14163, Germany

${ }^{4}$ Central Avian Research Institute, Izatnagar, Bareily-243122, India

${ }^{5}$ Department of Agronomy, Tamil Nadu Agricultural University, Coimbatore-641003, India

${ }^{6}$ Department of Veterinary Public Health and Epidemiology, Madras Veterinary College, Chennai-600007, India

${ }^{7}$ Department of Veterinary Microbiology, Madras Veterinary College, Chennai-600007, India

${ }^{8}$ Division of Biological standardization, Indian Veterinary Research Institute, Izatnagar-243122, India
}

Received - September 28, 2017; Revision - October 19, 2017; Accepted - December 08, 2017

Available Online - December 27, 2017

DOI: http://dx.doi.org/10.18006/2017.5(6).730.748

\section{KEYWORDS}

Japanese encephalitis virus

Virus genome

Transmission

Epidemiology

Diagnosis

Prevention

\begin{abstract}
Japanese encephalitis (JE) is an emerging mosquito-borne zoonotic disease caused by Japanese encephalitis virus (JEV). Geographic and ecological factors such as global warming and climate change affect the demographic distribution of arthropod vectors and thereby favour the risk of JE epidemics across the world. It has become a devastating human disease that affects paediatric age group but people of all ages may get an infection. Furthermore, nearly 67,900 JEV incidences are occurring every year in 24 countries of South-East Asia and Western Pacific regions, wherein 10,426 cases were reported only in 2011. Although the mechanism for JEV pathogenesis is imprecise yet, significant scales of differences are professed in peripheral pathogenicity and neurovirulence between JEV strains. In addition to humans, a large number of vertebrate animal hosts viz. cattle, sheep, goat, dog, cat, and chicken get JEV infection. Of the note, birds and pigs serve as effective viraemic hosts and may help in dissemination of the disease in nature. Intervention strategies like vaccination as well as alteration in
\end{abstract}

* Corresponding author

E-mail: malikyps@gmail.com (Yashpal Singh Malik)

Peer review under responsibility of Journal of Experimental Biology and Agricultural Sciences.

Production and Hosting by Horizon Publisher India [HPI] (http://www.horizonpublisherindia.in/).

All rights reserved.
All the article published by Journal of Experimental Biology and Agricultural Sciences is licensed under a Creative Commons Attribution-NonCommercial 4.0 International License Based on a work at www.jebas.org.

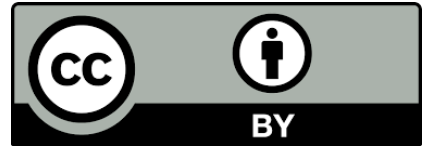


agricultural practices, health education, integrated vector control programme, strengthening of diagnostic facilities together with active surveillance programs along with the 'one health' approach might help to combat the emergence of this lethal pathogen and to safeguard human and animal health. This review abridges the updated information on virus genome, transmission, epidemiology, diagnosis and preventive measures to reduce the burden of JE amongst human and animal population.

\section{Introduction}

Japanese encephalitis (JE), an outrageous emerging mosquitoborne zoonotic disease, is caused by Japanese encephalitis virus (JEV) listed under Flaviviridae family (Saxena et al., 2013; Malhotra et al., 2015). A number of mosquito-borne viral diseases like Zika and Ebola have unrestrainedly spread in several parts of the world, even few claimed the status of "International Emergency" due to the disease associated losses (Dhama et al., 2015; Singh et al., 2016; Singh et al., 2017; Munjal et al., 2017). In the recent years, Japanese encephalitis has become an overall human health hazard, especially in South-east Asia, Pacific regions (Western) and Australia. Though individuals of all the age groups are vulnerable to JEV infections, predominantly it affects children (less than 14 years of age) in endemic regions. Mainly, JEV infections remain asymptomatic in humans, but $1 \%$ of infections result in clinical disease with a fatality rate of $20-30 \%$, further $30-50 \%$ of recovered individuals may undergo everlasting neuropsychiatric sequelae (Campbell et al., 2011; Sundari et al., 2016; Heffelfinger et al., 2017). JE is a notifiable disease as listed by World Organization for Animal Health (OIE) but its reporting is highly variable and incomplete due to lack of technology and observation in remote areas (Malhotra et al., 2015, More et al., 2017). Though actual incidence reports are still lacking, it was approximated that at present roughly 67,900 JEV incidences were occurring every year in 24 countries of South-East Asia and Western Pacific regions, wherein 10,426 cases reported in 2011 only (CDC, 2013). Recently, the global incidence of JE shows a progressive trend towards expansion along with geographical distribution. This review converses herein the virus genome, transmission, epidemiology, diagnosis and preventive measures to reduce the burden of JE amongst human and animal population.

\section{Etiology}

JEV is listed under family Flaviviridae which shares similarities with other arthropod-borne flaviviruses namely, St. Louis encephalitis virus, Dengue virus, West Nile virus (WNV), TickBorne Encephalitis virus (TBEV) and Yellow fever virus (YFV)(Klema et al., 2015). Initially, JEV was categorized in group B of arbovirus under the family Togaviridae and afterward in the year 1985, listed in genus Flavivirus under the Flaviviridae family (Westaway et al., 1985). The genus Flavivirus comprises of more than 70 closely related enveloped small viruses with SS positive sense RNA genome (Liang et al., 2016). JEV is labile and susceptible to ultraviolet light, gamma radiation and common disinfectants like phenol, iodophors, ethanol (70 \%), formaldehyde (3-8\%), iodine, glutaraldehyde (2\%), bleach (1\%), etc. In addition, JEV is inactive in acidic environmental conditions ( $\mathrm{pH}$ between 1.0 and 3.0) but remain infectious in alkaline environments (pH between 7.0 and 9.0) (OIE, 2017).

\section{Structure and Genome of the virus}

JEV is spherical in shape (40-50 $\mathrm{nm}$ in diameter), comprises of a lipid envelope decorated with glycoproteins containing an isometric nucleocapsid consists of single-stranded positive-sense RNA genome and core protein (Solomon et al., 2003). The genome contains single open reading frame (ORF) of about $11 \mathrm{~kb}$ size in which 5' end is capped and 3' end is not poly-adenylated with the potential to encode a large polyprotein of 3432 amino acids (Nain et al., 2017). This ORF carries genes for three structural proteins and seven non-structural proteins. The structural proteins are nucleocapsid or core protein (C), glycosylated envelope protein (E) and non-glycosylated membrane protein $(\mathrm{M})$. Further, non-structural proteins are abbreviated as NS1, NS2A, NS2B, NS3, NS4A, NS4B and NS5 (Lindenbach et al., 2007; Saxena et al., 2011).

The structural component of the nucleocapsid is formed by $\mathrm{C}$ protein (12-14 kDa) (Bharati \& Vrati, 2006). The 8-9 kDa M protein serves as a transmission anchor which has hydrophobic domains (McAda et al., 1987). The $M$ protein is initially synthesized as a precursor glycoprotein (prM) and cleaved to mature $\mathrm{M}$ protein by a furin-like cellular protease. It is worth to note here that incompletely cleaved prM act as an additional target on virions for neutralizing antibodies (Geiss et al., 2009). The envelope protein comprises of 3 domains (I, II and III) that helps in the penetration of the virion into host-cell, virulence, stimulation of neutralizing antibody and producing a protective immune response (Chambers et al., 1990). In addition, E protein acts as a major target for host antiviral immune response (Zhang et al., 2011). Non-structural proteins play a significant role in viral genome replication and expression. NS1 protein, a glycosylated protein found on the infected cell surface which may produce a deleterious response in the host if formed in huge amount 
(Saxena et al., 2013). Both E and NS1 proteins are more immunogenic proteins in the host against which neutralizing antibodies are mounted. NS1 protein-based approach is currently used for development of differentiating infected and vaccinated animals (DIVA) based vaccination strategies. NS2B and NS3 proteins work together as a virus-specific protease which cleaves the polyprotein in the ORF to generate 7 non-structural and 3 structural proteins (Yusof et al., 2000) while NS4A and NS4B involved in viral replication. Furthermore, NS3 also has helicase activity and 5'-RNA triphosphatase activity which needs to unwind the double-stranded RNA at some point in genome replication and 5'-RNA cap formation respectively (Klema et al., 2015). NS5 protein is largest JEV proteins which have viral RNA dependent RNA polymerase activity, responsible for the high mutation rate of JEV (Mukhopadhya et al., 2005).

\section{Serotype and Genotypes of JEV}

JEV isolates comprise of single serotype (Tsarev et al., 2000) with five genotypes (from I to $\mathrm{V}$ ) based on $\mathrm{E}$ and $\mathrm{C} / \mathrm{PrM}$ gene sequence (Li et al., 2011). Genotype I isolates were isolated from India, China, Cambodia, Japan, Malaysia, Korea, Taiwan, northern Thailand, Vietnam and northern Australia (Schuh et al., 2013). Genotype II has been reported sporadically in Indonesia, Malaysia, Northern Australia, Papua New Guinea and southern Thailand (Chen et al., 1992). Genotype III was the most commonly distributed genotype in temperate regions like India, China, Korea, Japan, Myanmar, Philippines, Nepal, Taiwan, Vietnam and Sri Lanka (Mackenzie et al., 2004). Genotype IV was only isolated from mosquitoes of Indonesia (Chen et al., 1992). In addition, the Muar strain was the proposed fifth genotype, isolated from a patient in Malaysia in 1952 and also from the outbreaks in China (Li et al., 2011) and South Korea (Kim et al., 2015) which differs genetically unlike other JEV genotypes (Mohammed et al., 2011).

Among all the genotypes isolated since 1935, 98\% of the strains belong to Genotypes I, II, and III (Chen and Yu, 2013). Genotypes I and III commonly occurs in the form of the outbreak in temperate zones, but II and IV are cause for widespread disease in tropical zones (Chen et al., 1992). Previously genotype III was the most widely distributed genotype in Asian countries including India with the prototype of Nakayama strain (Mackenzie et al., 2006) but in recent days genotype 1 is largely replacing genotype III (Gao et al., 2013).

\section{Pathology and pathogenesis of JEV}

The complete pathway for JEV pathogenesis is unclear but still significant scales of differences have been observed in peripheral pathogenicity and neurovirulence between JEV strains (Yang et al., 2011). The virus enters the host through the bite of an infected mosquito, proliferates quickly in the reticuloendothelial cells in the skin and moves to the central nervous system subsequent to short-lived viremia. JEV virion binds to endothelial surface in CNS and internalizes by cholesterol and clathrin-mediated endocytosis (Das et al., 2010). Later virus disseminates to the hippocampus, substantia nigra, hypothalamus and medulla oblongata, replicates in neurons and matures in neuronal secretary system. The virus invades into the CNS by damaging structural and functional integrity of the blood-brain barrier with the help of matrix metalloproteinases of the JEV and results in devastating consequences of the neurotropic JEV infection (Big et al., 2009; Gupta et al., 2010). A strong correlation was observed between JE infection and neurocysticercosis in a single study, which proposed that neurocysticercosis may one way or another prejudice to JE (Desai et al., 1997). JE mainly affects the anterior horn cells in the spinal cord, thalamus, cerebral cortex, and cerebellum. At acute infection, inflammation, edema, herniation and hemorrhagic symptoms are observed in the cerebrum (Tiroumourougane et al., 2002). Apart from neural tissues, lesions are also observed in the lymphoid tissues and immune cells in spleen and Kupffer cells (Saxena et al., 2013).

\section{Clinical features in humans}

JE is a devastating human disease that affects paediatric age group but peoples of all age may get the infection (Wu et al., 2017). Approximately $99 \%$ JEV infection are asymptomatic as described earlier; infection is symptomatic in less than one percent cases and characterized by encephalitis. The occurrence of symptomatic to asymptomatic infection ratio is 1: 25-1000 (1:300 on an average) (Saxena \& Dhole, 2008). The incubation period ranges between 5 and 15 days, and symptoms are pyrexia, chillness, lethargy, muscle ache, headache, abdominal pain and vomition (Hills et al., 2010).

In humans, infection is divided into three stages: (i) a prodromal stage, (ii) an encephalitis stage with obvious CNS symptoms and (iii) a convalescent-phase with persistence CNS damage. The first stage can develop over few days with an abrupt onset of nonspecific febrile illness with non-specific symptoms including diarrhea and rigors with a subsequent headache, vomition and abridged level of consciousness and convulsion (Tiroumourougane et al., 2002). This is followed by a second stage (third to the fifth day), evidenced by characteristic altered mental status, focal neurological deficits, ataxia, and generalized weakness, thereafter advance to confusion, delirium, and coma. Rarely signs of abnormal oculocephalic reflex, hemiparesis with hypertonia and decorticate and decerebrate posture were observed due to intracranial hypertension (Tiroumourougane et al., 2002) About $85 \%$ of kids and $10 \%$ of adults develops a generalized or focal seizure and $25 \%$ of encephalitis patients die within the first week due to neurological illness (David et al., 2010). Few peoples 
may manifest transient Parkinson's syndrome with signs of masked faces, the paucity of blinking, cogwheel rigidity with or without the tremor, akinesia and other extrapyramidal signs i.e. nodding of head, pill rolling activities, bizarre facial grimacing, choreoathetosis, myoclonus, and lip-smacking at some later stage of the illness. These features were reported in $20 \%-40 \%$ of Indian children (Solomon, 1997). Occasionally patients may develop poliomyelitis-like acute flaccid paralysis and other syndromes like pulmonary edema and gastric hemorrhage in absence of bleeding diathesis (Solomon, 1997). The mortality may rise up to $30 \%$ among patients with encephalitis (WHO, 2015). Convalescent/recovery stage is marked by slow recovery or persistence of signs. Complete recovery was noticed in patients only with mild disease whereas, in severe cases, $50 \%$ of the surviving patients may have everlasting psychiatric or neurologic sequelae i.e. behavioural disturbances, memory loss, impaired cognition, convulsions, motor weakness or paralysis and altered tone and coordination (Nett et al., 2009).

Clinical laboratory studies in JE patients are non-specific which includes moderate leukocytosis, mild anemia, thrombocytopenia, elevated hepatic enzymes, and hyponatremia. Cerebrospinal fluid (CSF) usually shows significant lymphocytic pleocytosis with moderately elevated protein (Solomon \& Vaughn, 2002). Reduction in iron levels in serum was observed as a regular finding in microbial incursion in JE infection (Singh et al., 2012a). Histopathological changes commonly occur in grey matter and lesions include meningitis, perivascular cuffing with lymphocytes, neuronophagia, neuronal degeneration and formation glial nodules by microglial proliferations (Tiwari et al., 2012).

\section{$7 \mathrm{JEV}$ infection in Animals}

Vertebrate animals including cattle, sheep, goat, dog, cat, and chicken have been reported to be infected with JEV and mostly remain asymptomatic (Pant et al., 2006). Viraemia is common in infected birds and pigs thereby help in the perpetuation of the disease in nature (Guerin \& Pozzi, 2005). Pigs play a vital role in JEV transmission cycle in humans. In pigs, viremia occurs without displaying any overt clinical signs, but infection of pregnant sows results in the mummified foetus, stillborn and weak piglets with subcutaneous edema and hydrocephalus (Acha \& Szyfres, 2003). JE infection is rare in cattle and characterized by neurological signs, and sometimes progressed as non-specific signs i.e. fever, decreased appetite, and depression.

In equines, infection is the inapparent and clinical picture is similar to human disease. Clinical signs appear 8 to 10 days after exposure and infection are characterized by pyrexia, loss of appetite, weakness, photophobia and neurologic disorder ranging from mild lethargy to hyper-irritability, loss of control of body movement, paresis followed by coma and death (Burke \& Monath, 2001). In addition, mortality rate ranges between 5 to 30 $\%$ (Gulati et al., 2011).

\section{Transmission}

JEV shows usual transmission cycle between mosquitoes and wading birds and/or pigs.Humans are considered as dead-end hosts and they may get the infection in the course of the bite of an infected mosquito, primarily Culex tritaeniorynchus. Hitherto, direct person to person transmission was not reported (Park, 2005). However, trans-placental transmission (Chaturvedi et al., 1980), laboratory-acquired infections (Steffen, 1987), blood and organ transplantation (Plesner, 2004) are described as a rare mode of transmission in humans. In pigs, infected boars showing highgrade viremia sheds JEV in semen (Guerin \& Pozzi, 2005). Transmission of JEV depends on pathogen, host, biology of vectors and their capacity and environmental factors i.e. climate and anthropogenic influences such as changes in agricultural practices, irrigation schemes, and urbanization which makes complex epidemiology (Cleaveland et al., 2007; Le Flohic et al., 2013)

\section{Vectors and reservoir hosts}

JEV virus exists in an enzootic mosquito-bird or mosquito-birdpig transmission cycle where vertebrate hosts like pigs, bat, and water birds a vital position in upholding and intensification of the virus, whereas invertebrate hosts like Culex spp. mosquitoes are conscientious for virus transmission (Singh et al., 2012b; Longbottom et al., 2017). Humans are the incidental host for JEV infection where subsequent transmission was not observed due to a short period of viremia with very low virus titer (Mokkappan et al., 2015; OIE, 2017). JEV is mainly spread by blood-sucking arthropod vectors in which virus multiplies in host tissues without evidence of disease or damage. C. tritaeniorhynchus is the main vector involved in the transmission of JEV in Asian continent whereas, in Northern Australia, C. annulirostris is the most important vector (Tiwari et al., 2012). C. vishnui complex (C. tritaeniorhynchus, C. vishnui and C. pseudovishnui) act as a principal vector of JEV which breeds in water bodies with luxuriant vegetation i.e. paddy fields, shallow ditches and pools and these vectors spread in highest density between June and November in temperate zones (Singh et al., 2012b). C. tritaeniorhynchus species is predominantly zoophilic, prefers to bite water birds, cattle, and pigs which leads to the circulation of the virus between mosquitoes and avian/livestock species and also acting as a "bridge vector" between livestock and humans (Le Flohic et al., 2013). C. tritaeniorhynchus feed during night time and shows two peaks of biting time i.e. few hours after sunset and in midnight (Longbottom et al., 2017). Mosquitoes become infected upon biting viraemic host and remain as a carrier 
for virus throughout the life. They can transfer the virus to other hosts subsequent to the extrinsic incubation period of $9-12$ days (Kumari et al., 2014). In addition, JEV has also been isolated from mosquito larvae which support vertical transmission and persistence of the infectious virus in the atmosphere (Mackenzie et al., 2006). In the endemic regions, up to $3 \%$ of the vector mosquitoes are found infected with JEV (Saxena et al., 2013). Apart from above-listed species JE virus has also been isolated from other mosquito species such as Mansonia indiana, $M$. uniform, C. gelidus, C. whitmorei, C. pipiens, C. epidesmus, Anopheles peditaeniatus, A. subpictus, , Aedes albopictus, Ae. detritus and Ae. japonicas (Impoinvil et al., 2011). These are the secondary vectors for JEV, but their role in transmission has not been confirmed and leads to the putative emergence of JEV under favourable conditions (de Wispelaere et al., 2017).

Ardeidae family water birds (i.e. cattle egrets and pond herons) act as important natural reservoirs as well as maintenance hosts for JEV and may also be responsible for the spread of JEV in virgin soil (Upadhyay \& Ahmad, 2011). Adult ducks and chickens are also susceptible to infection with JEV with low viremia but unlikely to substantial transmission to feeding mosquitoes (Cleton et al., 2014). However, hatched chicks might develop much higher viremia than adult birds which suggests their minor role in JEV transmission in endemic regions. Furthermore, JEV specific antibodies have been demonstrated in several species of wild and domestic birds (Acha \& Szyfres, 2003; Pant et al., 2006).

Pigs serve as amplifying hosts for JEV and significantly contributes to the dissemination of the disease in rural settings without showing any overt clinical signs except abortion and stillbirth in infected pregnant sows (Guerin \& Pozzi, 2005). It was estimated that JEV infects about $20 \%$ of the susceptible porcine population in every year with 1.2 basic reproductive numbers among pigs (Khan et al., 2014). Horses and humans are considered as dead-end hosts for JE infection. Even though, horses are the only animal species that develops encephalitis without high-grade viremia (Weaver \& Barrett, 2004). Other domestic animals like cattle, goat, sheep, dogs, and cats also infected subclinically with JEV with a low level of viremia, but they do not have any role in virus transmission (Pant et al., 2006). Rodents are not susceptible to infection, whereas reptiles, amphibians, and bats can be experimentally infected and the virus can persist for longer, but these host species role in overwintering in the environment is not clear (Mackenzie et al., 2004).

\section{Epidemiology}

Geographical distributions of the virus show a tendency in the direction of expansion which is hypothesized due to birds movement, animal smuggling, some irrigation projects and global warming (Diagana et al., 2007). Irrigated rice fields and pig breeding places create a favorable niche for vector proliferation (i.e. Culex tritaeniorhynchus mosquitoes) and attract wandering birds, thereby aids in virus spread (Jeffries \& Walker, 2015). Consequently, high risk of JE is associated with rural residents living in close proximity to rice plantations and pigsties. However, in some regions, anthrophilic urban mosquito species such as $C$. quinquefasciatus also act as a vector for JEV which indicates the change of epidemiological patterns as well as the emergence of JE infections in urban population (Mackenzie et al., 2006).

JE exhibits two patterns of disease transmission epidemiologically: (i) an endemic pattern in tropical areas of southern Asia (southern Vietnam, Southern Thailand, Indonesia, Malaysia, Philippines, Sri Lanka, and southern India) that occurs sporadically throughout the year with a peak after the start of the monsoon (July to September) and (ii) an epidemic pattern in temperate areas of northern Asia (northern Vietnam, northern Thailand, Korea, Japan, Taiwan, China, Nepal and Northern India) with clear summer seasonality (Vaughn \& Hoke, 1992; Wang \& Liang, 2015). In endemic countries, every year, JEV infects about $10 \%$ of the susceptible population and most of the infections were asymptomatic results in a non-specific flu-like illness (Tiroumourougane et al., 2002; Longbottom et al., 2017) JE infection mainly affects the paediatric groups (3 to 15 years of age), while adults are also affected during epidemics in new locations (Saxena \& Dhole, 2008). The incidence rates were less among kids of less than 3 years old than older children; presumably because of behavioural aspect like playing outside after dusk (Vaughn \& Hoke, 1992). Further, the rate of infection is more in males in many outbreaks which may possibly due to increased exposure in rice cultivation fields (Burke \& Monath, 2001).

\section{Geographical distribution}

\subsection{Global scenario}

JE was first reported in Tokyo, Japan during 1871 and following this, the first epidemic was described in Japan during 1924 involving over 6,000 cases. A decade later, a huge outbreak occurred in 1935 and subsequently regular outbreaks reported from 1946 to 1952, however, no JEV was isolated from any of these outbreaks (Pond \& Smadel, 1954). JEV was first isolated in 1934 from a fatal case of encephalitis patient's brain tissue and named as Nakayama strain of JEV (Mitamura, 1936). Succeeding epidemics of JE elucidated that the virus spread by mosquito vector and had a seasonal disease occurrence. Infections occur either as an epidemic or endemic in many South-Asian countries (Figure 1) including Japan, Korea, Taiwan, China, Vietnam, Thailand, Malaysia, Myanmar, India, Nepal, and Sri Lanka and nearly 3 billion people (approximately $60 \%$ of the world's 


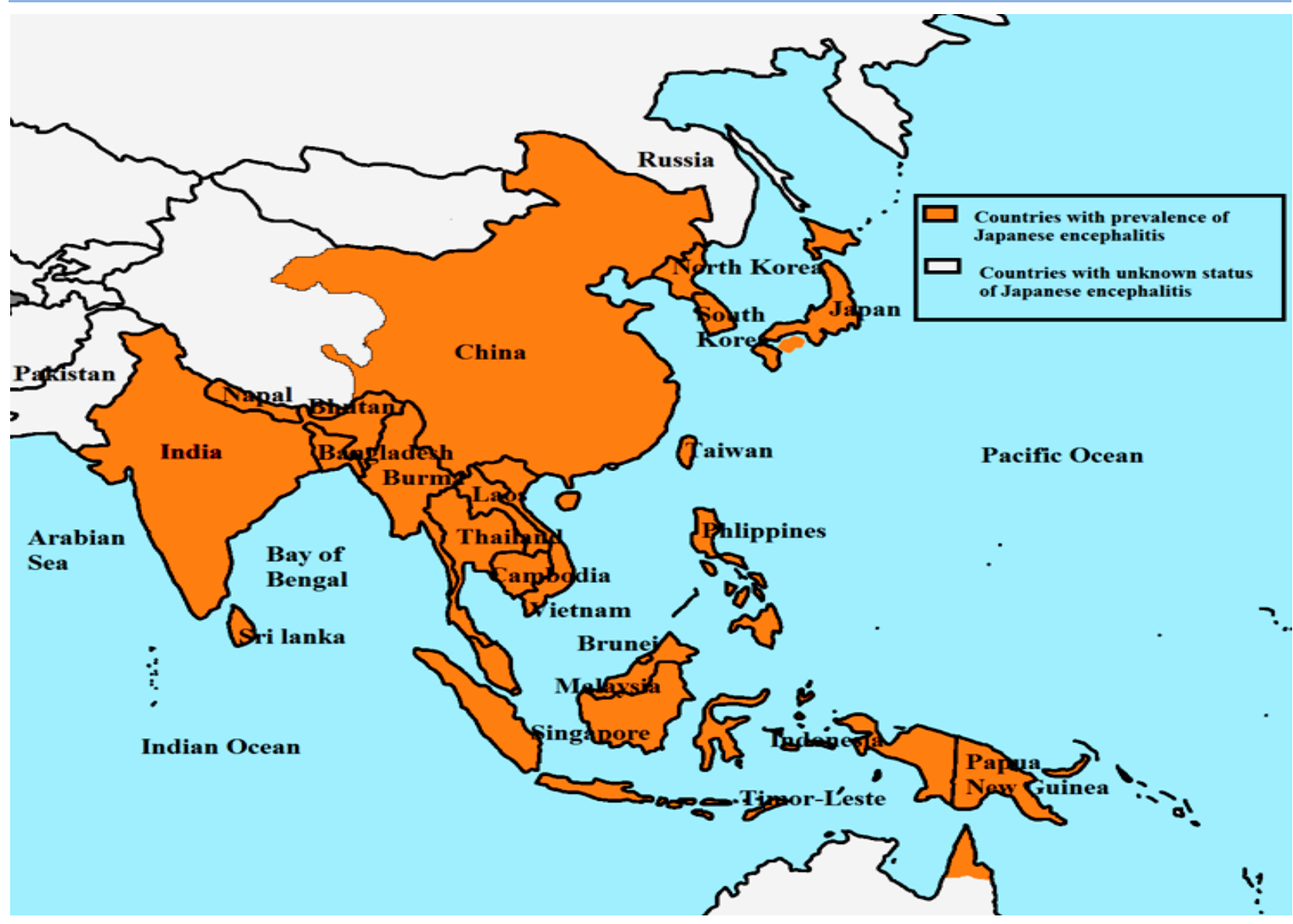

Figure 1 Geographic distribution of Japanese Encephalitis

population) are risk of contracting JEV infection via the bite of Culex mosquitoes (WHO, 2015). The global burden of JE estimated to be 709,000 disability-adjusted life years (Mathers et al., 2007) and total morbidity rate is about $1.8 / 100,000$ population (Gao et al., 2013). Among the countries, most numbers of JE cases was reported from China with the incidence of 5.4 per 100,000 and approximately $75 \%$ of infected persons were children of age between 0-14 years (Campbell et al., 2011). Recent studies revealed that most common Genotype III has been gradually superseded by Genotype I during the past two decades (Gao et al., 2013). Besides recent outbreaks, JEV genotype V after 1952 indicates changes in the JEV population dynamics and global emergence other genotypes JEV. The estimated incidence rate of JE among the travellers from non-endemic countries to Asia is $<1$ case per one million travellers (Pavli \& Maltezou, 2015).

\subsection{Indian scenario}

Paediatric cases of JE are common in India. The first case of JE was reported at Vellore district of Tamil Nadu in 1955
(Namachivayam \& Umayal, 1982). Later, between 1955 and 1966 about 65 cases were reported in South-India (Carey et al., 1968). A large outbreak was first reported in 1973; about 700 cases were reported with $42 \%$ case fatality rate at Bankura and Burdwan districts of West Bengal (Chakravarty et al., 1975). Subsequently, numerous JE outbreaks were recorded in several states of India and first JEV (GP78) was successfully isolated from the patient with fatal encephalitis brain tissue of in Gorakhpur district of Uttar Pradesh (Mathur et al., 1982). A devastating outbreak of JE in Gorakhpur district in 2005-07 surpassed all previous outbreaks and resulted in 103,389 cases with the mortality of 33,729 cases (Diagana et al., 2007). C. gelidus acts as an important secondary vector for JEV transmission in India apart from $C$. tritaeniorhynchus (Ramesh et al., 2015). In last 60 years, geographical range of JEV has significantly expanded with elevated epidemic action in several parts of Central and North India and the disease become endemic in various states viz. Andhra Pradesh, Assam, Bihar, Tamil Nadu, Haryana, Karnataka, Kerala, Manipur, Madhya Pradesh, Uttar Pradesh, Orissa, West Bengal and in Union territories of Goa \& Pondicherry (Ghosh \& 
Basu, 2009). Acute encephalitis syndrome surveillance in the hospital showed that approximately $25 \%$ of cases were caused by $\mathrm{JE}$ in the north and northeast India, and the incident is common among children (Bandyopadhyay et al., 2013).

In India, only JEV genotype III strains have been isolated till 2007, but genotype I has also emerged later and strains belonging to both genotypes were isolated during an outbreak in Gorakhpur in 2009 (Fulmali et al., 2011). The precise means by which Genotype I was introduced to India is not clear, but maybe possibly by wandering birds (Huang et al., 2010) or by the travellers from Genotype I endemic countries, it got introduced (Sarkar et al., 2012a). In addition, JEV circulating in Northern India, a novel mutation in domain II of the envelop gene was reported earlier (Pujhari et al., 2011). Among all states of India, Assam had the highest incidence of JE followed by Uttar Pradesh and West Bengal (NVBDCP, 2017). The incidence of JE in India is given in Figure 2 and 3.
No. of cases of JE

No. of deaths due to JE

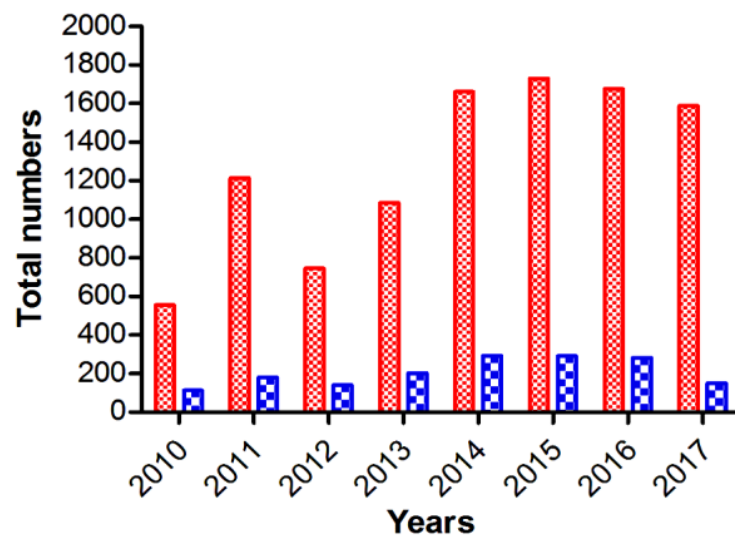

Figure 2 Incidence of Japanese Encephalitis in India since 2010 to 2017 (till October-2017).

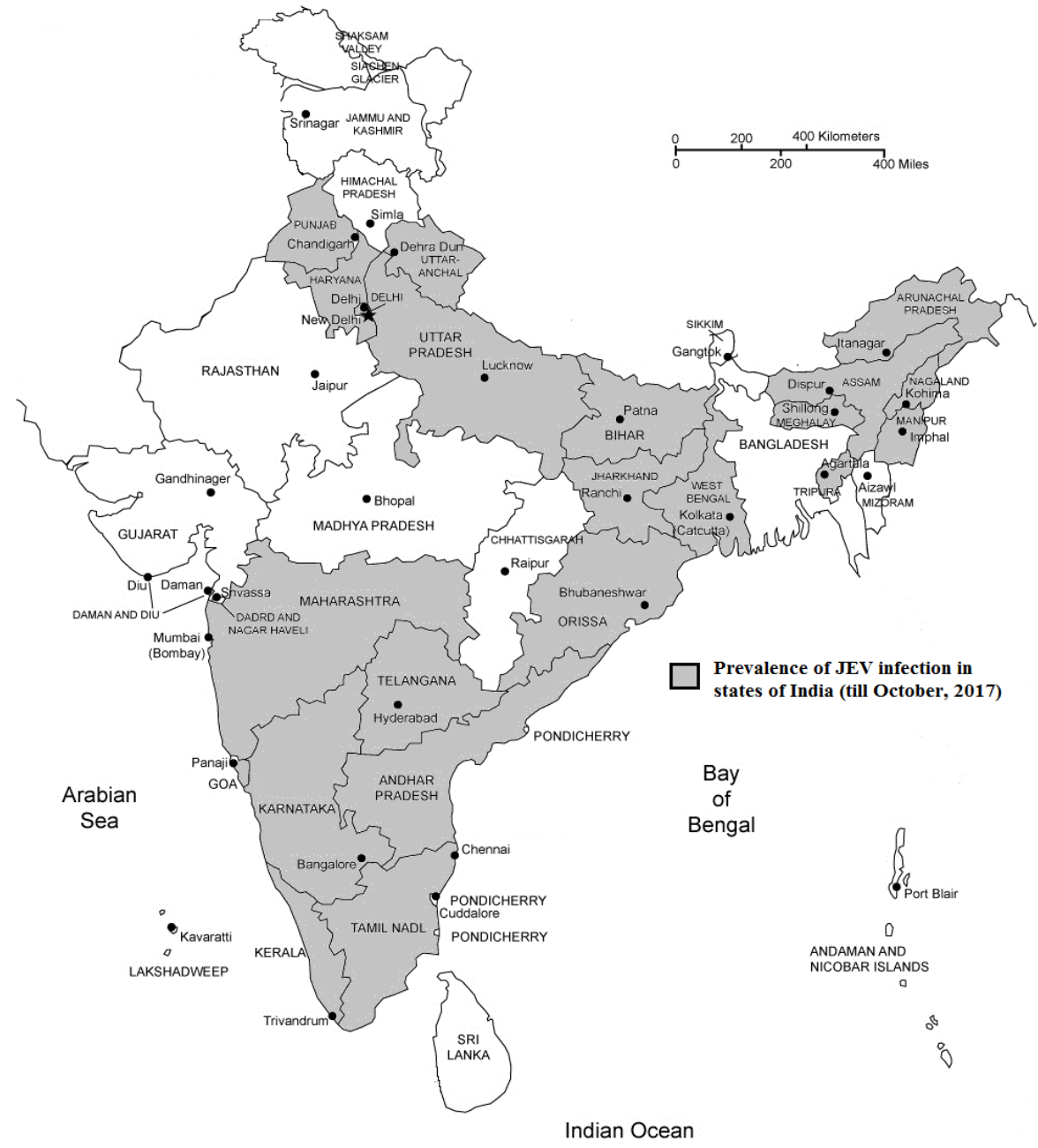

Figure 3 Occurrence of Japanese Encephalitis in India

Journal of Experimental Biology and Agriculture Science http://www.jebas.org 


\section{Diagnosis}

Accurate laboratory diagnosis of JE is essential to find out the disease load and trends to substantiate the need for immunization, to screen outcome of immunization programs and to advise of or authenticate the cause of the outbreak.

\subsection{Differential diagnosis}

JE infection is difficult to confirm based on clinical signs, and possible differential diagnosis includes cerebral malaria, Reye's syndrome and meningococcal infection in epidemic regions; whereas in non-epidemic areas, incompletely treated bacterial meningitis, tuberculous or fungal meningitis, para-meningeal infections or parasitic infections (toxoplasmosis and trichinosis), post-infectious encephalomyelitis, active demyelinating disease and other viral meningitis (Tiwari et al., 2012).

\subsection{Antigen detection assays}

JEV can be isolated in cell culture system, intra-cerebral inoculation of suckling mice and mosquito inoculation technique. Several cell lines including primary chicken, duck embryo cells, and lines of LLCMK2, Vero, AP61 and C6/36 cells are continuously used (Tiwari et al., 2012; Minakshi et al., 2014). However, virus isolation techniques are time-consuming and require a tedious procedure that demands more than a week for completion. Clinical specimens such as blood, serum, brain, CSF and spinal cord in equines, blood and aborted foetuses in case of pigs; CSF and brain tissues in humans and mosquitoes are suitable for virus isolation (Dhanze et al., 2014). Isolation of JEV from serum or CSF specimens is quite difficult due to the low level of transient viremia, instability of virus in environment and difficulty with transportation of specimens to a lab in developing countries (Parida et al., 2006).

Immunohistochemistry can be employed to identify JEV antigen in tissue sections in fatal cases of JE where CSF or serum is not available. About $62 \%$ of deadly cases of JE have been confirmed by immunohistochemical analysis for JE antigen in brain tissues (Zhi-Shang et al., 1988). Antigen capture ELISA is a speedy but positivity of the test is depends on the emergence of IgM specific antibodies in CSF which takes at least 7 days upon disease onset (Verma et al., 2015). Monoclonal antibodies against E protein is used for its high specificity to JEV, followed by a polyclonal antibody conjugate to enhance sensitivity and detection of multiple strains (Mei et al., 2012). Efficacy of other antigen detection tests such as reverse passive haemagglutination (Ravi et al., 1989), immunofluorescence (Raghava \& Badrinath, 1998) and staphylococcal coagglutination test (Zhang et al., 1989) also demonstrated with CSF from infected individuals.

\subsection{Molecular diagnosis}

Nucleic acid-based assays such as reverse transcription PCR (RT-PCR), quantitative real-time RT-PCR (qRT-PCR) and reverse transcription loop-mediated isothermal amplification (RTLAMP) were routinely used for detection of JEV (CDC, 2016; Mansfield et al., 2017). CSF could be a choice of sample for molecular diagnosis for JEV infections than blood in human due to low and transient viremia in JEV infections (Sarkar et al., 2012b). The conserved sequences such as 5' NTR, 3' NTR and NS1 region were commonly used for the diagnosis (Yang et al., 2004). RT-PCR-RFLP targeting single nucleotide polymorphism in the capsid $\mathrm{C}$ gene can be used to differentiate the Genotypes I and III (Zhang et al., 2014).

The qRT-PCR is a valuable tool which could able to detect various JEV strains and also distinguishes JEV strains from other flaviviruses. The Pan-Flavi assay (TaqMan probe-based qRTPCR) has been developed recently by targeting conserved NS5 gene region for a concurrent finding of different flaviviruses including YFV, WNV, TBEV, DENV, and JEV in a single-tube (Patel et al., 2013). JEV RT-LAMP assay has improved sensitivity compare to routine RT-PCR with equal sensitivity to qRT -PCR assay (Chen et al., 2011) with the detection limits ranging between 0.1 and 10 plaque forming units (PFUs) of virus (Toriniwa \& Komiya, 2006). Recently, digoxigenin was combined with the deoxycytidine triphosphate reaction mixture as a new detection method for detecting JEV in blood samples with low viral genome copies (Liu et al., 2009). RT-LAMP coupled with a lateral flow dipstick is used to detect multiple strains of JEV which eliminate the need for potentially unstable fluorescent dyes (Deng et al., 2015).

\subsection{Serological diagnosis}

Serological tests such as plaque reduction neutralization test (PRNT), indirect immunofluorescence assay (IFA), haemagglutination inhibition (HI) test, ELISA, and latex agglutination assay has been employed to detect JEV antibodies in serum or CSF from animals (OIE, 2016). However, serological tests have a limited value, which can be used only during the preliminary stage of an outbreak and in infrequent cases (Rao, 2001). Since the presence of antibodies in serum may not point out CNS connection, further IgM antibodies in CSF are more reliable for detection than serum IgM. The sensitivity of CSF IgM is about $80-90 \%$ when compared to $10 \%$ of serum IgM (Chang \& Tseng, 1993; Ogawa et al., 1992).

$\mathrm{HI}$ is the rapid and commonly used technique for diagnosis of JE in earlier days, but cross-reactivity among different flaviviruses and continuous need of goose RBCs limited the application in recent days (Erlanger et al., 2009). Presently, JEV specific IgM 
captures ELISA for serum and CSF was widely used as a standard test for diagnosis of JEV infection in both animals and humans. IgM antibodies specific for JEV can be identified in CSF and serum between 3 and 8 days after inception of disease and may remain for 1-3 months. This assay is sensitive and specific; however, heterologous flaviviral infections such as West Nile and Dengue viruses are a possible cause of false-positive reactions (Saxena \& Chitti, 2016). The PRNT is considered to be the gold standard serological test for JEV infection that can be used in regions where two or more flaviviruses circulate together and when it is difficult to differentiate samples using ELISA (Cha et al., 2014). Further, PRNT is recommended only in reference laboratories due to the risk of handling live virus which demands a Biosafety level 3 (BSL-3) conveniences and requirement of intensive labor and skilled personnel (Saxena \& Chitti, 2016).

Microsphere immunoassay (MIA) is a bead-based microfluidic system which offers higher sensitivity than other serological assays and one serum sample can be assessed against many flaviviral diseases to in a single run by multiplexing the assay. MIA with recombinant flavivirus EDIII antigens have been developed recently to detect and differentiate three zoonotic flavivirus infections of horses namely WNV, JEV, and TBEV which is responsible for encephalitis in humans (Beck et al., 2016).

\subsection{Serum biomarkers}

Serum protein profile is also useful as potential biomarkers for quick diagnosis of JEV illness. The analysis of serum proteins using surface-enhanced laser desorption/ionization-time of flightmass spectrometry (SELDI-TOF-MS) in combination with the ProteoMiner technology which precisely detects the lowabundance proteins in JEV infected patients which could be due to virus-induced effects (Upadhyay, 2013). Human macrophagederived factor (hMDF) is a one such serum biomarker secreted specifically during JEV infection which level rises to the highest point during the second week of infection. So, the finding of hMDF in blood possibly will serve as a helpful prognostic marker of the JE infection (Singh et al., 2012a).

\subsection{Biosensors}

In recent times, biosensor-based methods have been envisaged as a promising tool for rapid detection of JEV antigens in outbreaks as well as for preliminary screenings and to recompense the conventional diagnostic methods (Tuan et al., 2013). In addition to that, they necessitate no costly chemicals and provide an outcome in few minutes. Serum antibody-based biosensors can detect up to the $1-10 \mathrm{~g} \mathrm{JEV}$ antigens $/ \mathrm{ml}$ with a detection limit of $0.75 \mathrm{~g} / \mathrm{ml}$ (Huy et al., 2011) whereas electrochemical immunosensor developed using the APTES-GA-PrA-serum method (Tran et al., 2012) and Polyaniline nanowires (Tuan et al., 2013) detects the range between $25 \mathrm{ng} \mathrm{ml}-1$ and $1 \mu \mathrm{g} \mathrm{ml}-1$ of JEV antigens, and normal detection limit was about $10 \mathrm{ng} \mathrm{ml}-1$.

\subsection{Neuroimaging}

Non-invasive neuroimaging methods like magnetic resonance imaging (MRI), computed tomography (CT) and electroencephalography (EEG) can be used for the detection of cerebral lesions associated with JE in humans. MRI exhibits bilateral thalamic lesions with hemorrhagic regions, diffuse white matter edema and other structural abnormalities in basal ganglia, spinal cord, midbrain, pons, medulla, and cerebellum. Though thalamic lesions are most common and specific lesions associated with JE, they are not a very sensitive marker of JE (Dung et al., 2009). MRI lesions can be correlated with nature and extent of encephalitis and length of illness (Misra \& Kalita, 2010). CT scan is used to locate hyperintense changes in the cerebrum, thalamus, and cerebellum (Upadhyay, 2013). In addition, EEG gives diffuse delta pattern with spikes, theta waves and burst suppression in nerve cells in JE patients which are suggestive of anterior horn cell damage (Upadhyay, 2013).

\section{Prevention and control measures}

Prevention and control of JE largely depend on a combination of intervention measures such as immunization coverage, mosquito control, health education among the people and active surveillance.

\subsection{Vaccination}

Vaccination of people living in endemic areas, lab personnel with a possible for JEV exposure, travellers staying for more than one month in the prevalent zone and also to travellers staying less than a month during the JE transmission season is the reliable strategy for the prevention of JE (Fischer et al., 2010). At present, inactivated mouse brain-derived (Nakayama and Beijing-1) and Vero cell-based inactivated (Beijing-1, P-3, SA 14-14-2, Kolar strain-JEV 821564XY) vaccines are available. Concerns associated with cost, safety and efficacy of these vaccines have led to the development of other vaccines like live attenuated vaccine (SA14-14-2 from Chengdu Institute of Biological Products) and the chimeric live attenuated SA14-14-2 vaccines which are commercially available against JE (Paulke-Korinek \& Kollaritsch, 2008; Nickols et al., 2017).

\subsubsection{Mouse-brain derived inactivated JE vaccine}

Formalin-inactivated mouse brain vaccine based on Nakayama and Beijing-1 strains of JEV is available and later strain is widely used because of high cross-reactivity among other JEV strains. Primary immunization is performed between 1 and 3 years of age 
subcutaneously at doses of $0.5 \mathrm{~mL}$ to $1 \mathrm{~mL}$. About 3 doses $(0,7$ and 14/30 days) of vaccine along with one booster after one year and thereafter every 3 years until age 10 years are recommended (Malhotra et al., 2015). Although the vaccine is safe and effective, about $20 \%$ of the vaccinated people may develop local adverse reactions such as pain, swelling, and redness while $10 \%$ of people may suffer from common side effects like pyrexia, chillness, headache, rashes and myalgia (Fischer et al., 2010; Lindsey et al., 2010). Rarely, hypersensitivity due to the presence of thimerosal was reported which hampers the use of the vaccine in the rural areas, where the vaccine is immediately required (CDC, 2011). Because of the high cost of production and shortterm immunity of current vaccine, measures are directed towards the production of better vaccines.

\subsubsection{Cell-culture derived inactivated JE vaccine}

Primary hamster kidney cell culture-based inactivated Beijing-3 JEV strain vaccine was developed and being used since 1967 in China (Diagana et al., 2007). Cell culture derived vaccines are relatively easy to manufacture and efficacy was ranging between $76 \%$ and $90 \%$ following two injections (Srivastava et al., 2001). Vero cell culture-based P 20778 (Indian isolate) JEV strain vaccine, inactivated by formaldehyde, induced optimum neutralizing antibodies in serum in mice after two injections (Appaiahgari \& Vrati, 2004). However, Vero cell-derived JE vaccines cause allergic reactions to some people due to the presence of protamine sulfate (CDC, 2011).

\subsubsection{Cell-culture derived live attenuated JE vaccine}

SA 14-14-2 strain based live attenuated virus vaccine is currently used in Asian countries ( $\mathrm{Li}$ et al., 2013). The vaccine is made by pass aging the virus in weaning mice and later on growing in primary baby hamster kidney cells. The vaccine is cheap, safe and immunogenic with the seroprotection of $91 \%$ in primary immunization and $97 \%$ after secondary immunization (Kwon et al., 2015). Live attenuated SA14-14-2 vaccine is the first Chinese vaccine with safety and quality endorsed by WHO for use in children (Solomon et al., 2003).

\subsubsection{DNA vaccines}

Now-a-days, DNA based vaccines against JEV received great interest because of advantages like cost-effectiveness, safety, easy in production and may not obstruct with prevailing antibodies of other flaviviruses. DNA vaccines based on structural and nonstructural genes of JEV have been made and tested in animal models with variable efficacies. The first plasmid DNA vaccine pcDNA3JEME against JEV was made in 1998, which generated neutralizing antibodies with $70 \%$ protection in mice upon lethal challenge (Konishi et al., 2003). DNA vaccines encoding NS-1 gene has been shown to defend the mice against JEV by imparting strong antibody response (Lin et al., 1998). In a different study, mice were immunized with a plasmid DNA encoding the PrM and E proteins of JEV along with plasmid DNA encoding all nonstructural proteins. DNA with NS proteins provided partial protection than with PrM and E where neutralizing antibodies were formed (Konishi et al., 2003). Co-administration of plasmid encoding cytokines IL-2 and granulocyte-macrophage-colonystimulating factor along with DNA vaccine enhanced the level of protection in mice against JEV (Bharati et al., 2005). In addition, recombinant $\mathrm{E}$ protein vaccines with expression vectors like Escherichia coli (Saini \& Vrati, 2003; Rauthan et al., 2004) and baculovirus (Yang et al., 2005) were attempted. Vaxfectin (Nukuzuma et al., 2003) and poly-gamma-glutamic acid nanoparticles (Okamoto et al., 2008) were used as an adjuvant to improve the efficacy of DNA vaccine in animal models on which later was found to be a safe adjuvant for JE vaccine.

\subsubsection{YFV 17D-based chimeric vaccines}

JE-yellow fever chimeric vaccine is a novel recombinant vaccine licensed in Australia and Thailand. E and prM structural proteins from SA14- 14-2 (attenuated JEV) vaccine strain virus were integrated into the non-structural protein backbone of the 17D YFV vaccine strain (Monath et al., 2015). One dose of chimeric vaccine resulted in higher immunogenicity (equivalent to 3 doses of inactivated JE-MB) and enduring immunity equally in pre and post clinical vaccine trials (Beasley et al., 2004), which also produced immunity against the JEV genotypes I-IV in a mouse model (Reid et al., 2006). This vaccine is recommended to be administered from 2 years age and secondary immunization should be given following 12-24 months for children less than 18 years of age (Batchelor \& Petersen, 2015). Besides, mosquitoes fed with artificial blood meals containing high titers of chimeric JE vaccine were not infected with JEV which indicates that vaccinated individuals are less likely transfer the virus through mosquitoes (Guy et al., 2010).

\subsection{Vector control}

Vector control measure includes getting rid of mosquito breeding places, changing of pig sites and cleanliness of the environment. Mosquito control for JE can be used as a short-term measure during the epidemics. But for outer-urban places with marshland areas, use of insecticides like Malathion and pyrethrum compounds for fogging were suggested to prevent vector transmission (Tiroumourougane et al., 2002). But, recent studies showed a high level of resistance of mosquitoes to organophosphorus compounds and susceptibility to pyrethroids (Solomon, 2004). Application of natural insecticide such as "neem" to rice fields may be a more eco-friendly approach in addition to placing larvivorous fishes in rice paddies. Effective 
alternative strategies like better water management in rural areas, periodic water lowering, constant flow systems and intermittent irrigation of rice paddies to prevent the mosquito breeding can be used as long-term measures to control mosquitoes in endemic areas (Solomon, 2004). Recently, Wolbachia-based biocontrol has been postulated as an eco-friendly and cost-effective strategy which may have a significant impact on virus transmission as well as human cases of JE (Jeffries \& Walker, 2015). However, mosquito control measures in the rural areas have limited efficacy due to poor socio-economic conditions, the vastness of breeding places, the cost-effectiveness of the program and emergence of insecticide resistance in C. tritaeniorhynchus. Consequently, control of vector only cannot be depended to manage JE infections (Bharati \& Vrati, 2006).

\subsection{Public awareness}

General public/mass population should be made aware of the risks of acquiring JE infection. Effective sanitation and personal protection measures like use of bed nets impregnated with permethrin, insect repellents during peak biting hours, avoidance of outside sleeping during dawn and dusk and wearing longsleeved clothing to prevent JE occurrence through mosquito bites (Fischer et al., 2010).

\subsection{Protection of animal reservoirs}

Pigsties should not be constructed near human residences (at least 4-5 kilometres) and not be raised near horse studs to prevent virus amplification (Solomon, 2006). The animals should be housed indoors in screened stabling especially during outbreaks and peak vector activity. Providing fans, spraying residual insecticides in piggeries and mixed dwellings also provide protection from mosquitoes. Vaccination of pigs against JE may prevent JE infection in pigs thereby decreases amplification of virus and reduces the risk of abortion, but drawbacks like the high cost of vaccination and immunization of a large number of piglets in each breeding season need to be considered (Dhanze et al., 2014). Cell culture derived live-attenuated and inactivated virus vaccines are available for pigs in Taiwan and Japan; whereas infected cell culture or mouse brains based formalin-inactivated vaccines are used for horses in Japan (OIE, 2016). Even though pigs are vaccinated, circulation of the virus may still continue among birds (Dhanze et al., 2014).

\subsection{Surveillance}

Increased vector prevalence along with detection of JEV in mosquitoes and/or sudden appearance/raise of antibody titer in pigs against JEV can be used as an indicator to forecast or predict the outbreak of JE in humans (Dhanze et al., 2014). Hence, surveillance of JEV vectors renders data concerning prevalence, concentration, and a profusion of circulating viruses which would be a potent tool to create control strategies for JEV in humans and animals (Seo et al., 2013). Continuous surveillance of vectors coupled with seromonitoring in pigs is necessary to determine the virus activity in endemic regions of JEV (NVBDCP, 2014).

\subsection{Treatment}

At present, there is no approved therapeutic option available for the management of JEV infection and measures for development of potential antiviral agents are in progress (Baharuddin et al., 2014). Supportive care directed to control convulsions and maintenance of airway, fluid and electrolyte balance plays a key role in treatment efficacy during the acute phase. Although, treatment with diethyldithiocarbamate (Saxena et al., 2003), Lipid-complexed small interfering RNA (siRNA) (Kumar et al., 2006), Rosmarinic acid (Swarup et al., 2007), Pentoxifylline (Sebastian et al., 2009), Arctigenin (a lignin derived from the Greater Burdock (Arctiumlappa) (Hayashi, 2010), Peptideconjugated phosphorodiamidatemorpholino oligomers (Anantpadma et al., 2010), Minocycline (semi-synthetic derivative of tetracycline) (Dutta \& Basu, 2011), Tilapia hepcidin 1-5 (Antimicrobial peptide) (Huang et al., 2011), Griffithsin (Ishag et al., 2013), Bispidine (amino acid conjugate of 3,7diazabicyclononane) (Haridas et al., 2013), Mycophenolic acid (Sebastian et al., 2011), Luteolin (Fan et al., 2016) and anti-miR301a therapy (Hazra et al., 2017) have been found as promising candidates against JE infection that were attempted and showed protective effect in laboratory models. Their efficacy in the hospital settings is a big challenge which needs further assessment and increased availability to the needful. Conversely, uses of these therapeutic options are limited once patients begin to show neurological symptoms.

\section{Vaccination strategies in India}

Childhood JE vaccination programmes were implemented in India after the large outbreaks of JE in 2006 in several districts of Bihar and Uttar Pradesh. Immunization campaigns were conducted for the vaccination of children in outbreak areas (Universal Immunization Program, 2017). At present, active immunization is routinely carried out in $181 \mathrm{JE}$ endemic districts of India under Universal Immunization Program by using SA14-14-2 attenuated live virus vaccine (Vashishtha \& Ramachandran, 2015). The primary vaccination is administered subcutaneously at the age of 9-12 months of age followed by a booster between 16-18 months of age (Universal Immunization Program, 2017). In recent times, adult JE vaccination programme (>15-65 years) was also introduced in the $179 \mathrm{JE}$ highly prevalent districts under National immunization program to further reduce the disease occurrence in the country (Datta, 2014) In addition JENVAC vaccine is being routinely used in several states of the country, which showed 
higher serum antibody titres against JEV upon 28 and 56 days post immunization in comparison with SA14-14-2 vaccine. Further, more than $60 \%$ of the JENVAC immunized individuals had higher protective antibody titer in serum at 24 months after primary immunization when compared with SA14-14-2 vaccine (Singh et al., 2015).

\section{Conclusion and future prospects}

$\mathrm{JE}$ is a vector-borne neurotropic killer infection which emerged as a prime human health concern globally. Demographic and environmental factors such as global warming and climate change affect the geographical distribution of arthropod vectors and thereby favor the risk of JE epidemics across the world. Hence, implementation of effective vaccination coverage to susceptible population along with changes in agricultural practices, health education, integrated vector control programmes, strengthening diagnostic facilities coupled to active surveillance programs along with the 'one health' approach may help to combat the emergence of this deadliest pathogen and to safeguard human health.

\section{Author contributions}

All the authors substantially contributed to the conception, design, analysis, and interpretation of data, drafting and revising, updating, checking and approving the final version of the manuscript. We all agree to be accountability for the content of this manuscript.

\section{Funding}

This compilation is a review article written, analysed and designed by its authors and required no substantial funding to be stated.

\section{Acknowledgements}

All the authors acknowledge and thank their respective Institutes and Universities.

\section{Conflicts of interest}

All authors declare that there exist no commercial or financial relationships that could in any way lead to a potential conflict of interest.

\section{References}

Acha PN, Szyferz B (2003) Japanese encephalitis. In: Zoonoses and Communicable Diseases Common to Man and Animals. Vol. III, Chlamydioses, Rickettsioses and Viroses, 3rd edn, PAHO, NY, Washington DC, USA, 172-176.
Anantpadma M, Stein DA, Vrati S (2010) Inhibition of Japanese encephalitis virus replication in cultured cells and mice by a peptide-conjugated morpholino oligomer. Journal of Antimicrobial Chemotherapy 65: 953-961.

Appaiahgari MB, Vrati S (2004) Immunogenicity and protective efficacy in mice of a formaldehyde-inactivated Indian strain of Japanese encephalitis virus grown in Vero cells. Vaccine 22: 3669-75.

Baharuddin A, Hassan AA, Sheng GC, Nasir SB, Othman S, Yusog R, Othman R, Rahman NA (2014) Current approaches in antiviral drug discovery against the Flaviviridae family. Current Pharmaceutical Design 20: 3428-3444.

Bandyopadhyay B, Bhattacharyya I, Adhikary S (2013) Incidence of Japanese encephalitis among acute encephalitis syndrome cases in West Bengal, India. BioMed Research International 2013:896749.

Batchelor P, Petersen K (2015) Japanese encephalitis: a review of clinical guidelines and vaccine availability in Asia. Tropical Diseases, Travel Medicine and Vaccines 1:11-18.

Beasley DW, Li L, Suderman MT, Guirakhoo F, Trent DW, Monath TP, Shope RE, Barrett AD (2004) Protection against Japanese encephalitis virus strains representing four genotypes by passive transfer of sera raised against ChimeriVax-JE experimental vaccine. Vaccine 22: 3722-3726.

Beck C, Desprès P, Paulous S, Vanhomwegen J, Lowenski S, Nowotny N, Durand B, Garnier A, Blaise-Boisseau S, Guitton E, Yamanaka T (2016) A high-performance multiplex immunoassay for serodiagnosis of flavivirus-associated neurological diseases in horses. Journal of Equine Veterinary Science 39:S8-S9.

Bharati K, Appaiahgari MB, Vrati S (2005) Effect of cytokine encoding plasmid delivery on immune response to Japanese encephalitis virus DNA vaccine in mice. Microbiology Immunology 49:349-353.

Bharati K, Vrati S (2006) Japanese encephalitis: development of new candidate vaccines. Expert Review of Anti-infective Therapy 4: 313-324.

Big C, Reineck LA, Aronoff DM (2009) Viral Infections of the Central Nervous System: A Case-Based Review. Clinical Medicine and Research $7: 142-146$.

Burke DS, Monath TP (2001) Flaviviruses. In: Knipe DM, Howkey PM (Eds.) Fields Virology $\left(4^{\text {th }}\right.$ Edn.) Lippincott- Ravin Publishers, Philadelphia, PA, Pp. 1043-1125. 
Campbell GL, Hills SL, Fischer M, Jacobson JA, Hoke CH, Hombach JM, Marfin AA, Solomon T, Tsai TF, Tsu VD, Ginsburg AS (2011) Estimated global incidence of Japanese encephalitis: a systematic review. Bulletin World Health Organization 89: 766-774.

Carey DE, Myers RM, Pavri KM (1968) Japanese encephalitis studies in Vellore, South India. II. Antibody response of patients. Indian Journal Medical Research 56:1319-1329.

Centers for Disease Control and Prevention - CDC (2011) Update on Japanese encephalitis vaccine for children d United States, May, 2011. Morbidity and Mortality Weekly Report (MMWR) 60:664e5.

Centers for Disease Control and Prevention- CDC (2013) Japanese encephalitis surveillance and immunization in Asia and the Western Pacific 2012. Morbidity and Mortality Weekly Report (MMWR) 62:658e62.

Centers for Disease Control and Prevention- CDC (2016) Japanese Encephalitis Vaccine.

Cha GW, Cho JE, Ju YR, Hong YJ, Han MG, Lee WJ, Jeong YE (2014) Comparison of Four Serological Tests for Detecting Antibodies to Japanese Encephalitis Virus after Vaccination in Children. Osong Public Health and Research Perspectives 5 : 286-291.

Chakravarty SK, Sarkar JK, Chakravarty S, Mukherjee MK, Mukherjee KK (1975) The first epidemic of Japanese encephalitis studied in India virological studies. Indian Journal Medical Research 63: 77-82.

Chambers TJ, Hahn CS, Galler R, Rice CM (1990) Flavivirus genome organisation, expression and replication. Annual Review of Microbiology 44: 649-688.

Chang KJ, Tseng TC (1993) Seroepidemiological investigation on Japanese encephalitis in Taiwan (January 1989-December 1991). Zhonghua Min Guo Wei Sheng Wu Ji Mian Yi Xue Za Zhi 26: 25-37.

Chaturvedi UC, Mathur A, Chandra A, Das SK, Tandon HO, Singh UK (1980) Transplacental infection with Japanese encephalitis virus. Journal of Infectious Diseases 141: 712-715.

Chen N, Yu YX (2013) Progress in the research of phenotype and genotype of Japanese encephalitis virus in China. Bing Du Xu e Bao 29: 457-464.

Chen WR, Ricco-Hesse R, Tesh RB (1992) A new genotype of Japanese virus from Indonesia. American Journal of Tropical Medicine and Hygiene 47: 61-69.
Chen Z, Liao Y, Ke X (2011) Comparison of reverse transcription loop-mediated isothermal amplification, conventional PCR and real-time PCR assays for Japanese encephalitis virus. Molecular Biology Reports 38 : 4063-4070.

Cleaveland S, Haydon DT, Taylor L (2007) Overviews of pathogen emergence: which pathogens emerge, when and why? Current Topics in Microbiology and Immunology 315: 85-111.

Cleton NB, Bosco-Lauth A, Page MJ, Bowen RA (2014) AgeRelated Susceptibility to Japanese Encephalitis Virus in Domestic Ducklings and Chicks. American Journal of Tropical Medicine and Hygiene $90: 242-246$.

Das S, Chakraborty S, Basu A (2010) Critical role of lipid rafts in virus entry and activation of phosphoinositide 3' kinase/Aktsignaling during early stages of Japanese encephalitis virus infection in neural stem/progenitor cells. Journal of neurochemistry 115: 537-549.

Datta J (2015) Four vaccines added to India's immunisation programme. Available at http://www.thehindubusinessline.com/economy/policy/fourvaccines-added-to-indiasimmunisationprogramme/article6173880.ece. Accessed on June 18, 2017.

David WV, Alan B, Tom S (2010) Flaviviruses (Yellow fever, Dengue, Dengue Hemorrhagic Fever, Japanese Encephalitis, West Nile Encephalitis, St.Louis Encephalitis, Tick-Borne Encephalitis). In: Mandell LG, Bennett EJ, Dolin R (Eds.) Principles and practice of infectious diseases. 7th ed. Philadelphia: Churchill Livingstone Elsevier; 2010.p. 2133e51.

de Wispelaere M, Despres P, Choume V (2017) European Aedesalbopictus and Culexpipiens are Competent Vectors for Japanese Encephalitis Virus. PLoS Neglected Tropical Diseases $11: \mathrm{e} 0005294$

Deng J, Pei J, Gou H, Ye Z, Liu C, Chen J (2015) Rapid and simple detection of Japanese encephalitis virus by reverse transcription loop-mediated isothermal amplification combined with a lateral flow dipstick. Journal of Virological Methods 213: 98-105.

Desai A, Shankar SK, Jayakumar PN, Chandramuki A, GourieDevi M (1997) Coexistence of cerebral cysticercosis with Japanese encephalitis: A prognostic modulator. Epidemiology and infection 118: 165-171.

Dhama K, Malik YS, Malik SVS, Singh RK (2015) Ebola, from emergence to epidemic: the virus and the disease, global preparedness and perspectives. Journal of Infectious Disease Dev Countries 9 : 441-455. doi:10.3855/jidc.6197. 
Dhanze H, Chethan Kumar HB, Bhilegaonkar KN, Kumar A (2014) Japanese Encephalitis: A Veterinary Perspective. Journal of Foodborne and Zoonotic Diseases 2 : 59-67.

Diagana M, Preux PM, Dumas M (2007) Japanese encephalitis revisited. Journal of the Neurological Sciences 262: 165-170.

Dung NM, Turtle L, Chong WK (2009) An evaluation of the usefulness of neuroimaging for the diagnosis of Japanese encephalitis. Journal of Neurology 256:2052-2060.

Dutta K, Basu A (2011) Use of minocycline in viral infections. Indian Journal Medical Research 133: 467-470.

Erlanger TE, Weiss S, Keiser J, Utzinger J, Wiedenmayer K (2009). Past, present, and future of Japanese encephalitis. Emerging Infectious Diseases 15: 1-7.

Fan W, Qian S, Qian P, Li X (2016) Antiviral activity of luteolin against Japanese encephalitis virus. Virus Research 220: 112-116.

Fischer M, Lindsey N, Staples JE, Hills S (2010) Japanese encephalitis vaccines: recommendations of the advisory committee on immunization practices. Morbidity and Mortality Weekly Report 59: 1-27.

Fulmali PV, Sapkal GN, Athawale S, Gore MM, Mishra AC, Bondre VP (2011) Introduction of Japanese encephalitis virus genotype I, India. Emerging Infectious Diseases 17: 319-321.

Gao X, Liu H, Wang H, Fu S, Guo Z, Liang G (2013) Southernmost Asia is the source of Japanese encephalitis virus (genotype 1) diversity from which the viruses disperse and evolve throughout Asia. PLoS neglected tropical diseases 7:e2459.

Geiss BJ, Stahla H, Hannah AM, Gari HH, Keenan SM (2009) Focus on flaviviruses: current and future drug targets. Future Medicinal Chemistry 1: 327.

Ghosh D, Basu A (2009) Japanese encephalitis- a pathological and clinical perspective. PLoS Neglected Tropical Diseases $3: \mathrm{e} 437$.

Guerin B, Pozzi N (2005) Viruses in boar semen: detection and clinical as well as epidemiological consequences regarding disease transmission by artificial insemination. Theriogenology 63: 556-572.

Gulati BR, Singha H, Singh BK, Virmani N, Khurana SK, Singh RK (2011) Serosurveillance for Japanese encephalitis virus infection among equines in India Journal of Veterinary Science $12: 341-345$.
Gupta N, Lomash V, Rao PV (2010) Expression profile of Japanese encephalitis virus induced neuroinflammation and its implication in disease severity. Journal of Clinical Virology 49:4-10.

Guy B, Farshad G, Veronique B, Stephen H, Thomas P M (2010) Preclinical and clinical development of YFV 17D-based chimeric vaccines against dengue, West Nile and Japanese encephalitis viruses. Vaccine 28: 632-649.

Haridas V, Rajgokul KS, Sadanandan S, Agrawal T, Sharvani V, Gopalakrishna MVS, Bijesh MB, Kumawat KL, Basu A, Medigeshi GR (2013) Bispidine-Amino Acid Conjugates Act as a Novel Scaffold for the Design of Antivirals That Block Japanese Encephalitis Virus Replication. PLoS Neglected Tropical Diseases 7 : e2005.

Hayashi K, Narutaki K, Nagaoka Y, Hayashi T, Uesato S (2010) Therapeutic effect of arctiin and arctigenin in immunocompetent and immunocompromised mice infected with influenza A virus. Biological and Pharmaceutical Bulletin 33: 1199-1205.

Hazra B, Kumawat KL, Basu A (2017) The host microRNA miR301a blocks the IRF1-mediated neuronal innate immune response to Japanese encephalitis virus infection. Science Signaling 10: eaaf5185.

Heffelfinger JD, Li X, Batmunkh N, Grabovac V, Diorditsa S, Liyanage JB, Pattamadilok S, Bahl S, Vannice KS, Hyde TB, Chu SY, Fox KK, Hills SL, Marfin AA (2017) Japanese Encephalitis Surveillance and Immunization - Asia and Western Pacific Regions, 2016. Morbidity and Mortality Weekly Report (MMWR) 66:579-583.

Hills SL, Griggs AC, Fischer M (2010) Japanese encephalitis in travellers from non-endemic countries. American Journal of Tropical Medicine and Hygiene 82:930e6.

Huang HN, Rajanbabu V, Pan CY, Chan YL, Hui CF, Chen JY, Wu CJ (2011) Modulation of the immune-related gene responses to protect mice against Japanese encephalitis virus using the antimicrobial peptide, tilapia hepcidin 1-5. Biomaterials 32: 68046814.

Huang JH, Lin TH, Teng HJ, Su CL, Tsai KH, Lu LC, Lin C, Yang CF, Chang SF, Liao TL, Yu SK, Cheng CH, Chang MC, Hu HC, Shu PY (2010) Molecular epidemiology of Japanese encephalitis virus, Taiwan. Emerging Infectious Diseases 16: 876878.

Huy TQ, Hanh NTH, Thuy NT, Van Chung P, Nga PT, Tuan MA (2011) A novel biosensor based on serum antibody 
immobilization for rapid detection of viral antigens. Talanta 86 : 271-277.

Impoinvil DE, Solomon T, Schluter WW, Rayamajhi A, Bichha RP (2011) The spatial heterogeneity between Japanese encephalitis incidence distribution and environmental variables in Nepal. PLoS One 6: e22192.

Ishag HZA, Li C, Huang L, Sun MX, Wang F, Ni B, Malik T, Chen PY, Mao X (2013) Griffithsin inhibits Japanese encephalitis virus infection in vitro and in vivo. Archives of virology 158: 349358.

Jeffries CL, Walker T (2015) The Potential Use of WolbachiaBased Mosquito Biocontrol Strategies for Japanese Encephalitis. PLoS Neglected Tropical Diseases 9 : e0003576.

Mansfield KL, Hernandez Triana LM, Banyard AC, Fooks AR, Johnson N (2017) Japanese encephalitis virus infection, diagnosis and control in domestic animals. Veterinary Microbiology 201: 85-92.

Khan SU, Salje H, Hannan A, Islam MA, Bhuyan AM, Islam MA, Nahar N, Hossain MJ, Luby SP, Gurley ES (2014) Dynamics of Japanese encephalitis virus transmission among pigs in Northwest Bangladesh and the potential impact of pig vaccination. PLoS neglected tropical diseases $8: \mathrm{e} 3166$.

Kim H, Cha GW, Jeong YE, Lee WG, Chang KS, Roh JY (2015) Detection of Japanese Encephalitis Virus Genotype V in Culexorientalis and Culexpipiens (Diptera: Culicidae) in Korea. PLoS ONE 10: e0116547.

Klema VJ, Padmanabhan R, Choi KH (2015) Flaviviral replication complex: coordination between RNA synthesis and 5'RNA capping. Viruses 7 : 4640-4656.

Konishi E, Ajiro N, Nukuzuma C, Mason PW, Kurane I (2003) Comparison of protective efficacies of plasmid DNAs encoding Japanese encephalitis virus proteins that induce neutralizing antibody or cytotoxic T lymphocytes in mice. Vaccine 21:36753683.

Kumar P, Lee S K, Shankar P, Manjunath N (2006) A single siRNA suppresses fatal encephalitis induced by two different flaviviruses. PLoS Medicine 3:e96.

Kumari R, Sharma RS, Raina VK, Chauhan LS (2014) Role of Integrated Vector Management for Prevention and Control of Japanese Encephalitis/ Acute Encephalitis Syndrome (JE/ AES) A Review. Journal of Communicable Diseases 46 : 93 - 108.

Kwon H J, Lee SY, Kim KH, Kim DS, Cha SH, Jo DS, Kang JH (2015) The Immunogenicity and Safety of the Live-attenuated SA
14-14-2 Japanese Encephalitis Vaccine Given with a Two-dose Primary Schedule in Children. Journal of Korean Medical Science 30: 612-616.

Le Flohic G, Porphyre V, Barbazan P, Gonzalez JP (2013) Review of Climate, Landscape, and Viral Genetics as Drivers of the Japanese Encephalitis Virus Ecology. PLoS Neglected Tropical Diseases 7: e2208.

Li MH, Fu SH, Chen WX, Wang HY, Guo YH, Liu QY, Li YX, Luo HM, Da W, Duo Ji DZ, Ye XM, Liang GD (2011) Genotype $\mathrm{V}$ Japanese encephalitis virus is emerging. PLoS Neglected Tropical Diseases 5:e1231.

Li X F, Deng Y Q, Yang H Q, Zhao H, Jiang T, Yu X D, Li SH, Ye Q, Zhu SY, Wang HJ, Zhang Y (2013) A chimeric dengue virus vaccine using Japanese encephalitis virus vaccine strain SA14-14-2 as backbone is immunogenic and protective against either parental virus in mice and nonhuman primates. Journal of virology 87:13694-13705.

Liang H, Lee M, Jin X (2016) Guiding dengue vaccine development using knowledge gained from the success of the yellow fever vaccine. Cellular and Molecular Immunology 13: $36-46$.

Lin YL, Chen LK, Liao CL, Yeh CT, Ma SH, Chen JL, Chiang HY (1998) DNA Immunization with Japanese Encephalitis Virus Nonstructural Protein NS1 Elicits Protective Immunity in Mice. Journal of Virology 72: 191-200.

Lindenbach BD, Thiel HJ, Rice CM (2007) Flaviviridae: the viruses and their replication. In: Knipe DM, Howley PM (Eds), Fields virology, $5^{\text {th }}$ Ed., vol 1 Lippincott-Raven Publishers, Philadelphia, PA, Pp 1101-1152.

Lindsey NP, Staples JE, Jones JF, Sejvar JJ, Griggs A, Iskander J (2010) Adverse event reports following Japanese encephalitis vaccination in the United States, 1999-2009. Vaccine 29:58-64.

Liu Y, Chuang CK, Chen WJ (2009) In situ reverse-transcription loop-mediated isothermal amplification (in situ RT-LAMP) for detection of Japanese encephalitis viral RNA in host cells. Journal of Clinical Virology 46: 49-54.

Longbottom J, Browne AJ, Pigott DM, Sinka ME, Golding N, Hay SI, Moyes CL, Shearer FM (2017) Mapping the spatial distribution of the Japanese encephalitis vector, Culextritaeniorhynchus Giles, 1901 (Diptera: Culicidae) within areas of Japanese encephalitis risk. Parasites and Vectors 10:148.

Mackenzie JS, Williams DT, Smith DW (2006) Japanese Encephalitis Virus: The Geographic Distribution, Incidence, and 
Spread of a Virus with a Propensity to Emerge in New Areas. Perspectives in Medical Virology 16: 201-268.

Mackenzie S, Gubler DJ, Petersen LR (2004) Emerging flaviviruses: the spread and resurgence of Japanese encephalitis, West Nile and dengue viruses. Nature Medicine Supplement 10: S98-S109.

Malhotra S, Sharma S, Kumar P, Hans C (2015) Japanese Encephalitis and its Epidemiology. Journal of Infectious Diseases and Therapy 3: 243 .

Mathers CD, Ezzati M, Lopez AD (2007) Measuring the Burden of Neglected Tropical Diseases: The Global Burden of Disease Framework. PLoS Neglected Tropical Diseases 1: e114.

Mathur A, Chaturvedi UC, Tandon HO, Agarwal AK, Mathur GP, Nag D, Prasad A, Mittal VP (1982) Japanese encephalitis epidemic in Uttar Pradesh, India during 1978. Indian Journal Medical Research 75: 161-169.

McAda PC, Mason PW, Schmaljohn CS, Dalrymple JM, Mason TL, Fournier MJ (1987) Partial nucleotide sequence of the Japanese encephalitis virus genome. Virology 158: 348-360.

Mei L, Wu P, Ye J, Gao G, Shao L, Huang S, Li Y, Yang X, Chen H, Cao S (2012) Development and application of an antigen capture ELISA assay for diagnosis of Japanese encephalitis virus in swine, human and mosquito. Virology Journal 9:4.

Minakshi P, Ranjan K, Brar B, Ambawat S, Shafiq M, Alisha A, Kumar P, Ganesharao JV, Jakhar S, Balodi S, Singh A, Prasad G (2014) New approaches for diagnosis of viral diseases in animals. Advances in Animal and Veterinary Sciences 2: 55 - 63.

Misra UK, Kalita J (2010) Overview: Japanese encephalitis. Progress in Neurobiology 91: 108-120.

Mitamura T (1936) Study on Japanese encephalitis virus. Animal experiments and mosquito transmission experiments. Kansuilji 1: 260-270.

Mohammed MA, Galbraith SE, Radford AD, Dove W, Takasaki T, Kurane I, Solomon T (2011) Molecular phylogenetic and evolutionary analyses of Muar strain of Japanese encephalitis virus reveal it is the missing fifth genotype. Infection, Genetics and Evolution 11:885-862.

Mokkappan S, Basheer A, Iqbal N, Chidambaram S (2015) Bilateral thalamic bleed and cerebral venous sinus thrombosis in Japanese encephalitis. BMJ Case Reports 2015: 2014207957.

Monath TP, Seligman SJ, Robertson JS, Guy B, Hayes EB, Condit RC, Excler JL, Mac LM, Carbery B, Chen RT, Brighton
Collaboration Viral Vector Vaccines Safety Working Group (2015) Live virus vaccines based on a yellow fever vaccine backbone: standardized template with key considerations for a risk/benefit assessment. Vaccine 33: 62-72.

More S, Bicout D, Bøtner A, Butterworth A, Calistri P, Koeijer AD, Depner K, Edwards S, Garin-Bastuji B, Good M, Schmidt CG, Michel V, Miranda MA, Nielsen SS, Raj M, Sihvonen L, Spoolder H, Thulke H, Velarde A, Willeberg P, Winckler C, Bau A, Beltran-Beck B, Carnesecchi E, Casier P, Czwienczek E, Dhollander S, Georgiadis M, Gogin A, Pasinato L, Richardson J Riolo, F Rossi, G Watts M, Lima E, Stegeman JA (2017) Vectorborne diseases. EFSA Journal 15: 4793.

Mukhopadhyay S, Kuhn RJ, Rossmann, MG (2005) A structural perspective of the flavivirus life cycle. Nature Reviews Microbiology 3: 13-22.

Munjal A, Khandia R, Dhama K, Sachan S, Karthik K, Tiwari R, Malik YS, Kumar D, Singh RK, Iqbal HMN, Joshi S (2017) Advances in Developing Therapies to Combat Zika Virus: Current Knowledge and Future Perspectives. Frontiers in Microbiology 8: Article 1469. doi: 10.3389/fmicb.2017.01469.

Nain M, Mukherjee S, Karmakar SP, Paton AW, Paton JC, Abdin MZ, Basu A, Kalia M, Vrati S (2017) GRP78 is an important host factor for Japanese encephalitis virus entry and replication in mammalian cells. Journal of Virology 91:e02274-16.

Namachivayam V, Umayal K (1982) Proceedings of National Conference on Japanese Encephalitis (New Delhi: Indian Council of Medical Research Pp 30-33.

Nett RJ, Campbell GL, Reisen WK (2009) Potential for the emergence of Japanese encephalitis virus in California. VectorBorne and Zoonotic Diseases 9: 511-517.

Nickols B, Tretyakova I, Tibbens A, Klyushnenkova E and Pushko P (2017) Plasmid DNA launches live-attenuated Japanese encephalitis virus and elicits virus-neutralizing antibodies in BALB/c mice. Virology 512: 66-73.

Nukuzuma C, Ajiro N, Wheeler CJ, Konishi E (2003) Enhancing effect of vaxfectin on the ability of a Japanese encephalitis DNA vaccine to induce neutralizing antibody in mice; Viral Immunology 16: 183-189.

NVBDCP (2014) Operational Guidelines - National Programme for Prevention and Control of Japanese Encephalitis/ Acute Encephalitis Syndrome, 1-114.

NVBDCP (2017) Directorate General of Health services. Ministry of Health and Family Welfare. New Delhi. Available on http://nvbdcp.gov.in/je-cd.html access on 25th April, 2017. 
Ogawa S, Shrestha MP, Rai SK, Parajuli MB, Rai JN, Ghimire SC (1992) Serological and virological studies of Japanese encephalitis in the Terai region of Nepal. Southeast Asian Journal of Tropical Medicine and Public Health 23: 37-43.

OIE (World Organization for Animal Health) (2016) Japanese encephalitis. In: Manual of diagnostic tests and vaccines for terrestrial animals, Part II, Chapter 2.1.7, 1-11. Available on https://web.oie.int/eng/normes/MMANUAL/2008/pdf/2.01.07_JE V.pdf access on 29th April, 2017.

OIE (World Organization for Animal Health) (2017). Technical Disease Cards. Available on http://www.oie.int/animal-health-inthe-world/technical-disease-cards/ access on 29th April, 2017.

Okamoto S, Yoshii H, Ishikawa T, Akagi T, Akashi M, Takahashi M, Yamanishi K, Mori Y (2008) Single dose of inactivated Japanese encephalitis vaccine with poly (gamma-glutamic acid) nanoparticles provides effective protection from Japaneseencephalitis virus; Vaccine 26: 589-594.

Pant GR, Lunt RA, Rootes CL, Daniels PW (2006) Serological evidence for Japanese encephalitis and West Nile viruses in domestic animals of Nepal. Comparative Immunology, Microbiology and Infectious Diseases 29: 166-175.

Parida M, Dash PK, Tripathi NK, AmbujSannarangaiah S, Saxena P, Agarwal S, Sahani AK, Singh SP, Rathi AK, Bhargava R, Abhyankar A, Verma SK, Rao PV, Shekhar K (2006) Japanese Encephalitis Outbreak, India, 2005. Emerging Infectious Diseases 12: $1427-1430$.

Park K (2005) Japanese encephalitis. In: Park's Text Book of preventive and Social Medicine, M/S Banarsidas Bhanot Publisher's, Jabalpur, India, 228-229.

Patel P, Landt O, Kaiser M, Faye O, Koppe T, Lass U, Sall AA, Niedrig M (2013) Development of one-step quantitative reverse transcription PCR for the rapid detection of flaviviruses. Virology journal 10: 58 .

Paulke-Korinek M, Kollaritsch H (2008) Japanese encephalitis and vaccines: pastand future prospects. Wiener klinische Wochenschrift 120: 15-19.

Pavli A, Maltezou HC (2015) Travel-acquired Japanese encephalitis and vaccination considerations. The Journal of Infection in Developing Countries $9:$ 917-924.

Plesner AM (2004) Allergic reactions to Japanese encephalitis vaccine. Immunology and Allergy Clinics of North America 23: 665-697.
Pond WL, Smadel JE (1954) Neurotropic viral diseases in the Far East during the Korean War. Medical Science Publication, Army Medical Service Graduate School 4: 219-233.

Pujhari SK, Prabhakar S, Ratho RK, Modi M, Sharma M, Mishra B (2011) A novel mutation (S227T) in domain II of the envelope gene of Japanese encephalitis virus circulating in North India. Epidemiology and infection 139: 849-856.

Raghava PV, Badrinath S (1998) Detection of Japanese encephalitis cell associated antigen in CSF by indirect immunofluorescence. Annals of the National Academy of Medical Sciences (India) 34:207-211.

Ramesh D, Muniaraj M, Samuel PP, Thenmozhi V, Venkatesh A, Nagaraj J, Tyagi BK (2015) Seasonal abundance and role of predominant Japanese encephalitis vectors Culextritaeniorhynchus and Cx. gelidus Theobald in Cuddalore district, Tamil Nadu. The Indian Journal of Medical Research 142 : S23-S29.

Rao PN (2001) Japanese encephalitis. In: Nagabhushana Rao P (Ed.) Frontiers in Pediatric Neurology, Vol. V. Common Pediatric Neurological Problems, October 2001. Hyderabad, Neuroped Publication, Pp 1-70.

Rauthan M, Kaur R, Appaiahgari MB, Vrati S (2004) Oral immunization of mice with Japanese encephalitis virus envelope protein synthesized in Escherichia coli induces antiviral antibodies. Microbes and Infection 6: 1305-1311.

Ravi V, Premkumar S, Chandramuki A (1989) A reverse passive hemagglutination test for detection of JE virus antigen in cerebrospinal fluid. Journal of Virological Methods 23:291-3.

Reid M, Donna M, Andrew B, Natalie L, Kym L (2006) Experimental infection of Culexannulirostris, Culexgelidus, and Aedesvigilax with a yellow fever/Japanese encephalitis virus vaccine chimera (ChimeriVax-JE). American Journal of Tropical Medicine and Hygiene 75: 659-663.

Saini M, Vrati S (2003) High-level synthesis of Johnson grass mosaic virus coat protein in Escherichia coli and its auto assembly to form virus-like particles. Protein Expression and Purification 28: 86-92.

Sarkar A, Taraphdar D, Mukhopadhyay SK, Chakrabarti S and Chatterjee S (2012a) Molecular evidence for the occurrence of Japanese encephalitis virus genotype I and III infection associated with acute Encephalitis in Patients of West Bengal, India, 2010. Virology Journal 9:271.

Sarkar A, Taraphdar D, Mukhopadhyay SK, Chakrabarti S, Chatterjee S (2012b) Serological and molecular diagnosis of 
Japanese encephalitis revealsan increasing public health problem in the state of West Bengal, India. Transactions of the Royal Society of Tropical Medicine and Hygiene 106:15- 19.

Saxena SK, Chitti SV (2016) Introductory Chapter: Serum Components as Rapid Diagnostic Biomakers during Flavivirus Infection. In Proof and Concepts in Rapid Diagnostic Tests and Technologies. InTech publications.

Saxena SK, Mathur A, Srivastava RC (2003) Inhibition of Japanese encephalitis virus infection by diethyldithiocarbamate is independent of its antioxidant potential. Antiviral Chemistry and Chemotherapy 14:91-8.

Saxena SK, Tiwari S, Saxena R, Mathur A, Nair MPN (2011) Japanese Encephalitis: an Emerging and Spreading Arbovirosis: In Daniel R (Ed.), Flavivirus Encephalitis, InTech, Croatia (European Union), 295-316.

Saxena SK, Tiwari S, Saxena R, Mathur A, Nair MPN (2013) Japanese Encephalitis Virus. The Complex Biology of an Emerging Pathogen, Encephalitis Intech publications pp. 161-182.

Saxena V, Dhole TN (2008) Preventive strategies for frequent outbreaks of Japanese encephalitis in Northern India. Journal of Biosciences 33:505-514.

Schuh AJ, Guzman H, Tesh RB, Barrett ADT (2013) Genetic Diversity of Japanese Encephalitis Virus Isolates Obtained from the Indonesian Archipelago Between 1974 and 1987. Vector Borne and Zoonotic Diseases 13: 479-488.

Sebastian L, Desai A, Madhusudana SN, Ravi V (2009) Pentoxifylline inhibits replication of Japanese encephalitis virus: a comparative study with ribavirin. International Journal of Antimicrobial Agents 33: 168-173.

Sebastian L, Madhusudana SN, Ravi V, Desai A (2011) Mycophenolic acid inhibits replication of Japanese encephalitis virus. Chemotherapy 57: 56-61.

Seo HJ, Kim HC, Klein TA, Ramey AM, Lee JH (2013) Molecular detection and genotyping of Japanese encephalitis virus in mosquitoes during a 2010 outbreak in the Republic of Korea. PLoS One 8: e55165.

Singh A, Kulshreshtha R, Mathur A (2012a) Detection of a neutrophil chemotactic factor in Japanese encephalitis patients. Journal of Pharmaceutical and Scientific Innovation 1:23-26.

Singh A, Mitra M, Sampath G, Venugopal P, Rao JV, Krishnamurthy B, Gupta MK, Sri Krishna S, Sudhakar B, Rao NB, Kaushik Y (2015) A Japanese encephalitis vaccine from India induces durable and cross-protective immunity against temporally and spatially wide-ranging global field strains. The Journal of infectious diseases $212: 715-25$.

Singh A, Saxena SK, Srivastava AK, Mathur A (2012b) Japanese encephalitis: A persistent threat. Proceedings of the National Academy of Sciences, India Section B: Biological Sciences 82: 55-68.

Singh RK, Dhama K, Malik YS, Ramakrishnan MA, Karthik K, Tiwari R, Khandia R, Munjal A, Saminathan M, Sachan S, Desingu PA, Kattoor JJ, Iqbal HMN, Joshi SK (2017) Ebola Virus - Epidemiology, Diagnosis and Control: Threat to Humans, Lessons Learnt and Preparedness Plans- an Update on its 40 Year's Journey. Veterinary Quarterly 37: 98-135. Doi: 10.1080/01652176.2017.1309474.

Singh RK, Dhama K, Malik YS, Ramakrishnan MA, Karthik K, Tiwari R, Saurabh S, Sachan S and Joshi SK (2016) Zika Virus Emergence, Evolution, Pathology, Diagnosis and Control: Current Global Scenario and Future Perspectives - A Comprehensive Review. Veterinary Quarterly DOI: 10.1080/01652176.2016.1188333.

Solomon T (1997) Viral encephalitis in Southeast Asia. Neurological Infections and Epidemiology 2: 191-199.

Solomon T (2004) Japanese encephalitis vaccine. In: Jong EC, Zuckerman JN (Eds.) Travelers Vaccines. Canada: B.C. Decker; 2004:219-256.

Solomon T (2006) Control of Japanese encephalitis-within our grasp?. The New England Journal of Medicine 355: 869-871.

Solomon T, Ni H, Beasley DW, Ekkelenkamp M, Cardosa MJ, Barrett AD (2003) Origin and evolution of Japanese encephalitis virus in Southeast Asia. Journal of Virology 77: 3091-3098.

Solomon T, Vaughn DW (2002) Pathogenesis and clinical features of Japanese encephalitis and West Nile virus infections. Current Topics in Microbiology and Immunology 67:171-94.

Srivastava AK, Putnak JR, Lee SH, Hong SP, Moon SB (2001) A purified inactivated Japanese encephalitis virus vaccine made in Vero cells. Vaccine 19: 4557-4565.

Steffen R (1987) Vaccinating against Japanese encephalitis. Lancet 2: 511 .

Sundari S, Poovazhagi V, Santhosh G (2016) Japanese Encephalitis: Profile and Outcome from an Urban Pediatric Institute. Research Journal of Pharmaceutical, Biological and Chemical Sciences 7: 89-93.

Swarup V, Ghosh J, Ghosh S, Saxena A, Basu A (2007) Antiviral 
and anti-inflammatory effects of rosmarinic acid in an experimental murine model of Japanese encephalitis. Antimicrobial agents and chemotherapy 51: 3367-3370.

Tiroumourougane SV, Raghava P, Srinivasan S (2002) Japanese Viral encephalitis. Postgraduate Medical Journal 78: 205-215.

Tiwari S, Singh RK, Tiwari R, Dhole TN (2012) Japanese encephalitis: a review of the Indian perspective. Brazilian Journal of Infectious Diseases 16: 564-573.

Toriniwa H, Komiya T (2006) Rapid detection and quantification of Japanese encephalitis virus by real-time reverse transcription loop-mediated isothermal amplification. Microbiology and Immunology $50: 379-387$.

Tran QH, Nguyen THH, Mai AT, Nguyen TT, Vu QK, Phan TN (2012) Development of electrochemical immunosensors based on different serum antibody immobilization methods for detection of Japanese encephalitis virus. Advances in Natural Sciences: Nanoscience and Nanotechnology 3: 015012.

Tsarev SA, Sanders ML, Vaughn DW, Innis BL (2000) Phylogenetic analysis suggests only one serotype of Japanese encephalitis virus. Vaccine 18: 36-43.

Tuan CV, Huy TQ, Hieu NV, Tuan MA, Trung T (2013) Polyaniline nanowires-based electrochemical immunosensor for label free detection of Japanese encephalitis virus. Analytical Letters 46: 1229-1240.

Universal Immunization Program, Immunization Division at MoHFW. Available at http://www.nhp.gov.in/sites/ default/files/pdf/immunization_uip.pdf accessed on August 05, 2017.

Upadhyay RK (2013) Biomarkers in Japanese Encephalitis: A Review. BioMed Research International 591290.

Upadhyay RK, Ahmad S (2011) Japanese encephalitis virus (JEV): Its epidemiology, disease and vector control with special reference to immune surveillance and safety measures: A review. Journal of Pharmacy Research 4: 2490-2499.

Vashishtha VM, Ramachandran VG (2015) Vaccination policy for Japanese encephalitis in India: Tread with caution!. Indian pediatrics $52: 837-839$.

Vaughn DW, Hoke CH (1992) The epidemiology of Japanese encephalitis: prospects for prevention. Epidemiologic Reviews 14: 197-221.

Verma RK, Singh DP, Yadav R, Rawat R (2015) Comparative evaluation of antigen detection ELISA and reverse transcriptase PCR in acute stage of Japanese encephalitis prevalent in endemic areas of North-Eastern part of Uttar Pradesh, India. International Journal of Research in Medical Sciences 3: 3217-3223.
Wang H, Liang G (2015) Epidemiology of Japanese encephalitis; past, present, andfuture prospects. Therapeutics and Clinical Risk Management 11: 435-48.

Weaver SC, Barrett ADT (2004) Transmission cycles, host range, evolution and emergence of arboviral disease. Nature Reviews Microbiology 2: 789-801.

Westaway EG, Brinton MA, Gaidamovich S, Horzinek MC, Igarashi A (1985) Flaviviridae. Intervirology 24: 183-192.

WHO (2015) Japanese Encephalitis Vaccines. The Weekly Epidemiological Record 90:69-87.

Wu YH, Chen JM, Su CY (2017) Occurrence of old age Japanese Encephalitis: Current situation in Taiwan. Journal of the Formosan Medical Association 116: 915-918. doi: 10.1016/j.jfma.2017.04.010.

Yang D, Kweon C, Kim B, Lim S, Kim S, Kwon J, Han H (2004) TaqMan reverse transcription polymerase chain reaction for the detection of Japanese encephalitis virus. Journal of Veterinary Science 5: 345-351.

Yang DK, Kweon CH, Kim BH, Lim SI, Kwon JH, Kim SH, Song JY, Han HR (2005) Immunogenicity of baculovirus expressed recombinant proteins of Japanese encephalitis virus in mice. Journal of Veterinary Science 6: 125-133.

Yang Y, Ye J, Yang X, Jiang R, Chen H, Cao S (2011) Japanese encephalitis virus infection induces changes of mRNA profile of mouse spleen and brain. Virology Journal 8: 80 .

Yusof R, Clum S, Wetzel M, Krishna Murthy HM, Padmanabhan R (2000) Purified NS2B/NS3 serine protease of dengue virus type 2 exhibits cofactor NS2B dependence for cleavage of substrates with dibasic amino acids in vitro. Journal of Biological Chemistry 275: 9963-9969.

Zhang L, Tian G, Shi S (2014) Development of a RT-PCR-RFLP assay for differentiation of Japanese encephalitis virus genotype I and genotype III. Acta Veterinaria Et Zootechnica Sinica 45: $1555-1560$.

Zhang Y, Chen P, Cao R, Gu J (2011) Mutation of putative Nlinked glycosylation sites in Japanese encephalitis virus premembrane and envelope proteins enhances humoral immunity in BALB/C mice after DNA vaccination. Virology Journal 8: 138.

Zhang YH, Yu WF, Cai J (1989) A rapid method for detection of flavivirus antigens - staphylococcal co-agglutination test using monoclonal antibodies to Japanese encephalitis virus. Acta Virology 33: 24-31.

Zhi-shang L, Song-fang H, Nian-lin G (1988) Immunohistochemical study on Japanese B encephalitis. Chinese Medical Journal 101: 768-771. 